\title{
ANALISIS KEKERINGAN HIDROLOGI BERDASARKAN METODE AMBANG BATAS (THRESHOLD LEVEL METHOD) DI DAERAH ALIRAN SUNGAI KEDUANG KABUPATEN WONOGIRI
}

\author{
Bagas Dwi Purwantoro' ${ }^{1)}$, Rintis Hadiani' ${ }^{2)}$, Solichin ${ }^{3)}$ \\ 1) Mahasiswa Fakultas Teknik, Prodi Teknik Sipil, Universitas Sebelas Maret \\ 2) Pengajar Fakultas Teknik, Prodi Teknik Sipil, Universitas Sebelas Maret \\ 3) Pengajar Fakultas Teknik, Prodi Teknik Sipil, Universitas Sebelas Maret \\ J1. Ir. Sutami 36A, Surakarta 57126; Telp. 0271-634524. \\ Email : aradeabagas@gmail.com
}

\begin{abstract}
Abstrak
Fenomena yang sering terjadi di Indonesia yang juga merupakan bencana tahunan yang melanda beberapa wilayah adalah kekeringan. Salah satu wilayah yang menjadi tinjauan adalah di Daerah Aliran Sungai Keduang yang berada di Kabupaten Wonogiri Jawa Tengah. Kekeringan hidrologi juga dapat dideteksi melalui debit. Penelitian ini bertujuan mengetahui nilai Indeks Kekeringan Hidrologi (IKH) dan mengetahui kriteria kekeringan berdasarkan defisit dan surplus yang terjadi menggunakan analogi kriteria dari Oldeman yang kemudian dapat dipetakan ke dalam ArcGIS.

Penelitian ini berupa pengumpulan data, analisis data, dan interpretasi hasil analisis untuk mendapatkan informasi guna pengambilan keputusan dan kesimpulan. Perhitungan debit dilakukan dengan metode NRECA dan kemudian diambil threshold Q50 dan Q80 dengan distribusi gamma. Analisis kekeringan menggunakan metode Threshold Level Method di DAS Keduang dan kemudian krieria kekeringan berdasarkan pada kriteria bulan kering dari Hadiani, R., tahun 2009 yang merupakan analogi dari kriteria kering Oldeman. Didapat hubungan antara indeks kekeringan hidrologi dengan debit 15 harian dan dilakukan pemetaan pada ArcGIS.

Tujuan dari penelitian ini untuk mengetahui defisit serta indeks kekringan di DAS Keduang. Hasil analisis menunjukan bulan kering berpotensi terjadi pada bulan Juli - bulan Oktober pada periode kering dengan Indeks Kekeringan Hidrologi paling tajam sebesar - 0,0677 yang masuk pada kategori amat sangat kering di DAS Keduang. Grafik yang didapat dengan scatter plot didapatkan garis yang linear dengan persamaan garis $y=385,24 x+27,876$. Hasilnya kemudian dipetakan ke dalam ArcGIS agar diketahui bagaimana persebaran kekeringannya.

Kata Kunci : Metode Ambang Batas, DAS Keduang, Indeks Kekeringan Hidrologi, Kriteria Kering.

Abstrack

The phenomenon which occurs frequently in Indonesia, which is also an annual disaster that hits several regions is drought. One of the regions that are observed is Keduang Watershed in Wonogiri Regency, Central Java. Hydrological drought could also be detected through flow. This study aims to find out the value of the Hydrological Drought Index and the drought criteria based on the deficits and surpluses that occur by using Oldeman's analogy of criteria which then could be mapped into ArcGIS.

This study is in the form of data collection, data analysis and interpretation of the results of the analysis to acquire information for decision making and conclusion. The flow calculation is carried out using NRECA method and then Q50 and Q80 thresholds are taken with gamma distribution. Drought analysis uses Threshold Level Method in Keduang Watershed and then drought criteria is based on the dry month criteria of Hadiani, R., in 2009, which is an analogy of Oldeman's dry criteria. The correlation between bydrological drought index and 15-day flow was acquired and mapping into ArcGIS was done.

The objective of this research is to determine the deficit and drought index in Keduang $W$ atershed. The result of the analysis shows that the dry month has the potential to occur in July-October in the dry period with the most intense Hydrological Drought Index of - 0,0677 which is categorized as the driest in Keduang Watershed. The graph acquired by scatter plot shows a linear line with the line equation of $y=385,24 x+27,876$. The result was then mapped into ArcGIS to find out how the drought spreads.

Keywords: Threshold Method, Keduang Watershed, Hydrological Drought Index, Dry Criteria.
\end{abstract}




\section{PENDAHULUAN}

Sumber daya alam yang paling penting dan mendasar dalam kehidupan manusia adalah air. Air merupakan sumber daya alam yang dapat diperbarui melalui perputaran atau yang disebut siklus hidrologi, dimana perubahan iklim wilayah sangat mempengaruhi siklus hidrologi tersebut dan menjadi penyebab banyak sedikitnya air yang terdapat di wilayah tersebut (Julian W., 2016).

Bengawan Solo sebagai sungai terpanjang di Indonesia yang melintasi dua provinsi dan mengalir dari kabupaten Wonogiri, Jawa Tengah sampai dengan Gresik, Jawa Timur punya peran penting untuk menjaga keseimbangan lingkungan dan kepentingan sosial-ekonomi wilayah sekitarnya. Sungai ini memiliki empat daerah aliran sungai yaitu DAS Bengawan Solo, DAS Kali Girindulu dan Kali Lorog di pacitan, DAS kecil di pantai utara jawa, DAS Kali Lamong, DAS Bengawan Solo Hulu, Sub DAS Kali Madiun dan Sub DAS Bengawan Solo Hilir (bttp://mww.pu.go.id/main/view_pdf/5407). Salah satu Daerah Aliran Sungai yang terkena dampak kekeringan yaitu Daerah Aliran Sungai Keduang.

Untuk mengetahui tingkat kekeringan dapat digunakan metode ambang batas (Threshold Level Method) yang dapat memprediksi limpasan yang diturunkan dari persamaan neraca air (Amiluddin \& Wahyuningsih, 2015). Kekeringan hidrologi juga dapat dideteksi melalui debit (Rintis, 2009). Karena tidak memiliki stasiun debit, maka debit bisa diperoleh berdasarkan data curah hujan harian dengan metode NRECA. Dari hasil perhitungan tersebut maka akan dibuat grafik korelasi antara indeks dan debit serta peta persebaran kekeringan menggunakan Software ArcGIS.

Tujuan dari analisis dalam penilitian ini yaitu mengetahui indeks kekeringan hidrologi serta ketersediaan air dalam Daerah Aliran Sungai (DAS) Keduang, mengetahui pemetaan persebaran kekeringan.

\section{TINJAUAN PUSTAKA}

Suatu kejadian alam yang berpengaruh terhadap ketersediaan air yang digunakan untukkebutuhan manusia maupun vegetasi yaitu kekeringan. Hal tersebut menunjukkan suatu keadaan dimana kualitas dan kuantitas air yang tersedia tidak dapat memenuhi kebutuhan (Suryanti, 2008).

Sistem Informasi Geografis (SIG) dapat mempermudah penggambaran suatu informasi yang memuat mengenai koordinat dan lokasi dipermukaan bumi (Raharjo, 2011).

Faktor Penyebab Kekeringan tidak hanya disebabkan oleh berkurangnya curah hujan tetapi juga disebabkan karena faktor metereologis, ketidak seimbangan alam, kekurangan kelembaban tanah, tingkat partisipasi masyarakat (Adi, 2011).

\section{DASAR TEORI}

\section{Karakteristik Hujan}

Data hujan yang diperoleh sebelum diolah dilakukan uji kepanggahan, setelah itu dilakukan pengolahan data hujan wilayah menggunakan metode Thiessen.

Hujan rerata daerah aliran sungai dapat dhitung menggunakan persamaan (1):

$P=\sum_{i=1}^{n} P_{i} W_{i}$ 
dengan :

$\mathrm{P} \quad=$ Hujan rata-rata DAS $(\mathrm{mm})$,

$\mathrm{P}_{i} \quad=$ Kedalaman hujan di stasiun $I(\mathrm{~mm})$,

$\mathrm{W}_{i} \quad=$ Bobot stasiun,

$\mathrm{A}_{i} \quad=$ Luas daerah yang diwakili stasiun $i$,

A $\quad=$ Luas DAS,

$\mathrm{n} \quad=$ Jumlah stasiun hujan.

\section{Evapotransprasi}

Evapotranspirasi merupakan banyaknya air yang digunakan untuk proses pertumbuhan tanaman (transpirasi) dan evaporasi tanah (SNI 7745 : 2012). Evapotranspirasi dihitung berdasarkan metode Penman Monteith dengan input data klimatologi berupa temperatur, kelembaban, kecepatan angina, dan lama radiasi.

Perhitungan evapotranspirasi potensial dapat dihitung menggunakan persamaan (2) :

$\mathrm{ET}_{\mathrm{o}}=\frac{0.408 \Delta(R n-G)+\gamma \frac{900}{T+273} u_{2}\left(e_{s}-e_{a}\right)}{\Delta+\gamma\left(1+0.34 u_{2}\right)}$

dengan :

ETo = Evapotranspirasi acuan $(\mathrm{mm} /$ hari $)$,

$\mathrm{Rn}=$ Radiasi netto pada permukaan tanaman $\left(\mathrm{MJ} / \mathrm{m}^{2} / \mathrm{hari}\right)$,

$\mathrm{G}=$ Kerapatan panas terus-menerus pada tanah $\left(\mathrm{MJ} / \mathrm{m}^{2} /\right.$ hari),

$\mathrm{T}=$ Temperatur harian rata-rata pada ketinggian $2 \mathrm{~m}\left({ }^{\circ} \mathrm{C}\right)$,

$\mathrm{u}_{2}=$ Kecepatan angin pada ketinggian $2 \mathrm{~m}(\mathrm{~m} / \mathrm{s})$,

$\mathrm{e}_{\mathrm{s}} \quad=$ Tekanan uap jenuh $(\mathrm{kPa})$,

$\mathrm{e}_{\mathrm{a}} \quad=$ Tekanan uap aktual $(\mathrm{kPa})$,

$\Delta=$ Kurva kemiringan tekanan uap $\left(\mathrm{kPa} /{ }^{\circ} \mathrm{C}\right)$,

$\gamma=$ Konstanta psychrometric $\left(\mathrm{kPa} /{ }^{\circ} \mathrm{C}\right)$.

Yang kemudian dihitung dengan program Minitab 16.

\section{Ketersediaan Air}

Perhitungan ketersediaan air dihitung menggunakan metode NRECA dengan komponen proses yang berupa data hujan,evapotranspirasi, keseimbangan air di permukaan tanah, serta tampungan air tanah.

Data dan asumsi yang diperlukan dalam perhitungan metode NREC $A$ yaitu sebagai berikut:

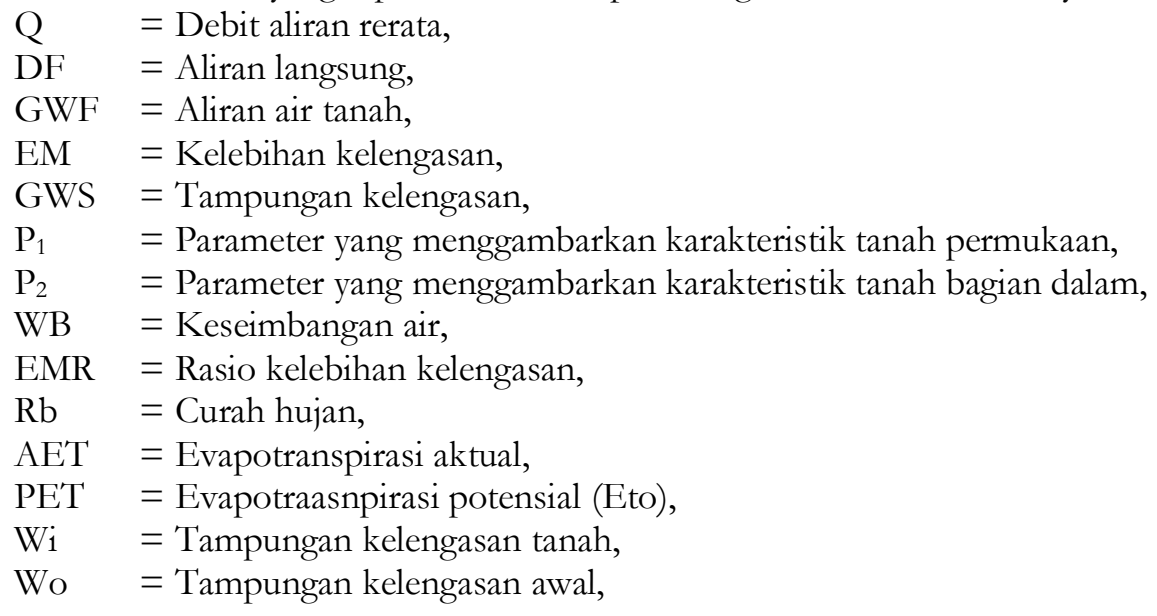




$$
\begin{array}{ll}
\mathrm{N} & =\text { Nominal, } \\
\mathrm{Ra} & =\text { Curah hujan tahunan. }
\end{array}
$$

\section{Penentuan Ambang Batas dan Q80}

Berdasarkan kriteria data debit maka perlu dilakukan perhitungan debit andalan (Q80) dan debit normal (Q50) dengan menggunakan Distribusi Gamma. Eksperimen probabilitas yang hasilnya menunjukkan suatu bentuk distribusi yang mempunyai variasi ukuran kemencengan yang cukup signifikan dapat diselesaikan dengan distribusi Gamma (Hatmoko,2011).

$$
F(x: \alpha, \beta)=\frac{1}{\beta^{u} \Gamma(\alpha \alpha} x^{\alpha-1} e^{-x \beta} \quad x \geq 0
$$

Yang selanjutnya dihitung dengan Minitab 16.

\section{Perhitungan Defisit dengan Metode Ambang Batas}

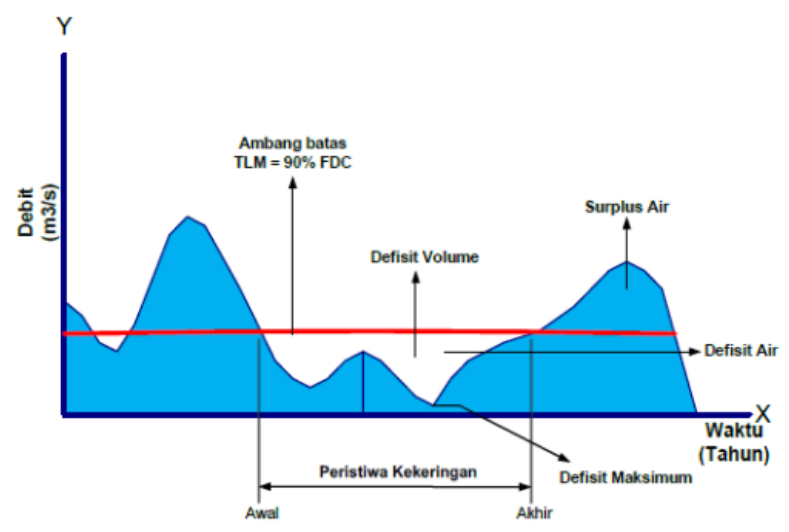

Gambar. 1 Threshold Level

Dalam menganalisis defisit debit menggunakan Threshold Level Method dapat dilakukan perhitungan untuk analisis waktu seri defisit. Selain itu, metode ini digunakan untuk menganalisis nilai minimum dan juga maksimumnya. Perhitungan Q50 digunakan untuk memperoleh nilai ambang batas. Nilai ambang batas dapat diatur dalam waktu yang tetap sepanjang tahun (konstan), musiman (1-4 musim), bulanan, N-hari dan setiap hari.

\section{Kriteria Kering}

Kriteria kekeringan dapat ditentukan dengan berbagai cara antara lain Kriteria kering berdasarkan data debit normal sama dengan Q50 dengan kriteria (Hadiani,2009) :

1. Disebut kering $(\mathrm{K})$ apabila $\mathrm{Q} 80<\mathrm{Q}<\mathrm{Q} 50$

2. Disebut sangat kering (SK) apabila $(71-100 \%)$ Q80

3. Disebut amat sangat kering (ASK) apabila $\mathrm{Q}<(70 \%) \mathrm{Q} 80$

Dengan :
Q80 = debit andalan,
Q50 = debit normal,
Q $\quad=$ debit defisit. 


\section{Indeks Kekeringan Hidrologi}

Debit merupakan semua aliran air yang masuk ke dalam sungai dari Daerah Aliran Sungai (DAS). Sehingga indeks kekeringan hidrologi merupakan perbandingan antara defisit terhadap luas DAS (Tallaksen, 2004).

$\mathrm{IKH}=\frac{\text { defisit } \mathrm{m}^{3} / \text { detik }}{\text { luas das } \mathrm{km}^{2}}$

Dengan IKH = Indeks Kekeringan Hidrologi.

\section{METODE PENELITIAN}

\section{Data}

Data yang dibutuhkan dalam analisis perhitungan penelitian yaitu data curah hujan harian beserta koordinat stasiun hujan DAS Temon (Batuwarno, Baturetno, Ngancar) kurun waktu 15 Tahun (2003 - 2017), peta rupa bumi skala $1: 25000$, data klimatologi dengan rentang waktu 15 Tahun $(2003-2017)$.

\section{Lokasi Penelitian}

Penelitian dilakukan di Daerah Aliran Sungai (DAS) Keduang yang terletak pada 7o 49' 48' - 70 52' 51,88” LS dan 110 49' 56,70" - 110 52' 38,5” BT Kabupaten Wonogiri,Provinsi Jawa Tengah. Lokasi penelitian Daerah Aliran Sungai (DAS) Keduang dapat dilihat pada gambar 2.

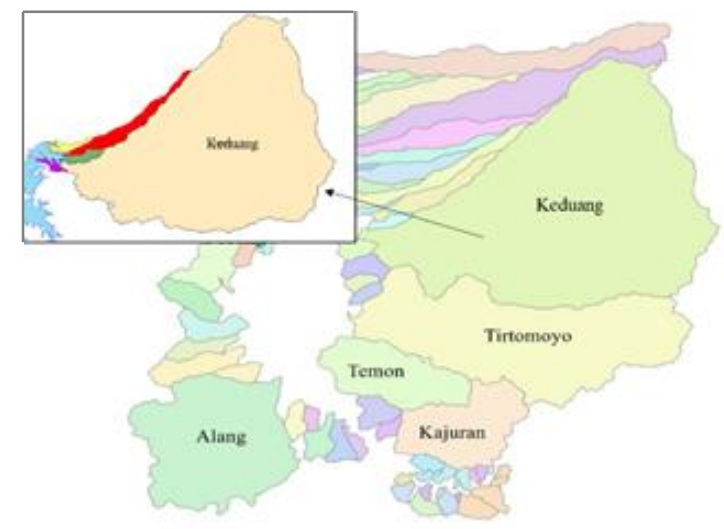

Gambar 2 Lokasi Penelitian

\section{Tahapan Penyelesaian Studi}

a. Pengumpulan data sekunder.

Pengisian data yang hilang menggunakan metode Reciprocal.

b. Pengujian data

Data yang diperoleh diuji menggunakan konsistensinya menggunakan metode RAPS.

c. Perhitungan evapotranspirasi

Evapotranspirasi dihitung menggunakan metode Penman Monteith, dengan input berupa suhu, kelembaban, kecepatan angin, dan lama penyinaran.

d. Perhitungan ketersediaan air

Perhitungan ketersediaan air dihitung menggunakan metode NRECA.

e. Perhitungan indeks kekeringan

Indeks kekeringan pada penelitian ini menggunakan metode Ambang Batas dengan membentuk grafik antara debit dengan waktu. 
f. Pemetaan indeks kekeringan

g. Grafik korelasi antara debit dan indeks

\section{HASIL DAN PEMBAHASAN}

\section{Pengujian Konsistensi Data}

Berdasarkan hasil uji konsistensi data hujan menggunakan RAPS pada Daerah Aliran Sungai

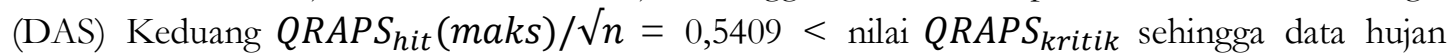
dianggap panggah dan dapat digunakan untuk perhitungan indeks kekeringan menggunakan metode Ambang Batas.

\section{Analisis Hujan Titik menjadi Hujan Wilayah}

Untuk menentukan hujan wilayah di Daerah Aliran Sungai (DAS) Keduang menggunakan metode Polygon Thiessen dengan tinjauan 3 stasiun hujan dan luasan DAS Keduang sebesar $427,9972 \mathrm{~km}^{2}$. Setelah dianalisa didapatkan koefisien thiessen dari masing-masing stasiun yaitu Pos Girimarto dengan luas 91,1498 maka koefisien thiessen sebesar 0,213; Pos Jatiroto dengan luas 147,2192 maka koefisien thiessen sebesar 0,3439; Pos Jatipurno dengan luas 189,6282 maka koefisien thiessen sebesar 0,4431 .

\section{Evapotranspirasi Potensial}

Evapotranspirasi dihitung menggunakan metode Penman Monteith. Besar nilai evapotranspirasi potensial pada bulan Januari periode I tahun 2008 yaitu sebesar 42,61 mm.

\section{Perhitungan Ketersediaan Air}

Perhitungan ketersediaan air dihitung berdasarkan metode NREC $A$ dengan input berupa data curah hujan dan evapotranspirasi dengan parameter berupa nilai nominal, PSUB, GWF, SMS dan GWS.

\section{Perhitungan Ambang Batas dan Q80}

Perhitungan menggunakan distribusi Gamma yang dihitung dengan menggunakan software Minitab 16. Didapat nilai $\mathrm{Q} 50=28,9369 \mathrm{~m}^{3} /$ detik dan debit andalan $(\mathrm{Q} 80)$ sebesar 22,0094 $\mathrm{m}^{3} /$ detik

\section{Indeks Kekeringan}

Indeks kekeringan diperoleh berdasarkan analisis perhitungan defisit dan surplus debit menggunakan metode ambang batas disbanding dengan luas DAS.

\section{Klasifikasi Kekeringan}

Klasifikasi kekeringan dengan menggunakan data debit NRECA yang kemudian diklasifikasikan kekeringannya berdasarkan kriteria kering Hadiani, 2009.

\section{Grafik Korelasi Debit dan Indeks}


Grafik korelasi antara debit ketersediaan air dan indeks kekeringan dibuat bertujuan untuk mengetahui trend bencana kekeringan yang terjadi di Daerah Aliran Sungai (DAS) Keduang. Grafik hubungan antara debit ketersediaan air dan indeks kekeringan pada tahun terbasah dan terkering ditampilkan pada Gambar 3.

\section{Grafik Hubungan Indeks dengan Debit}

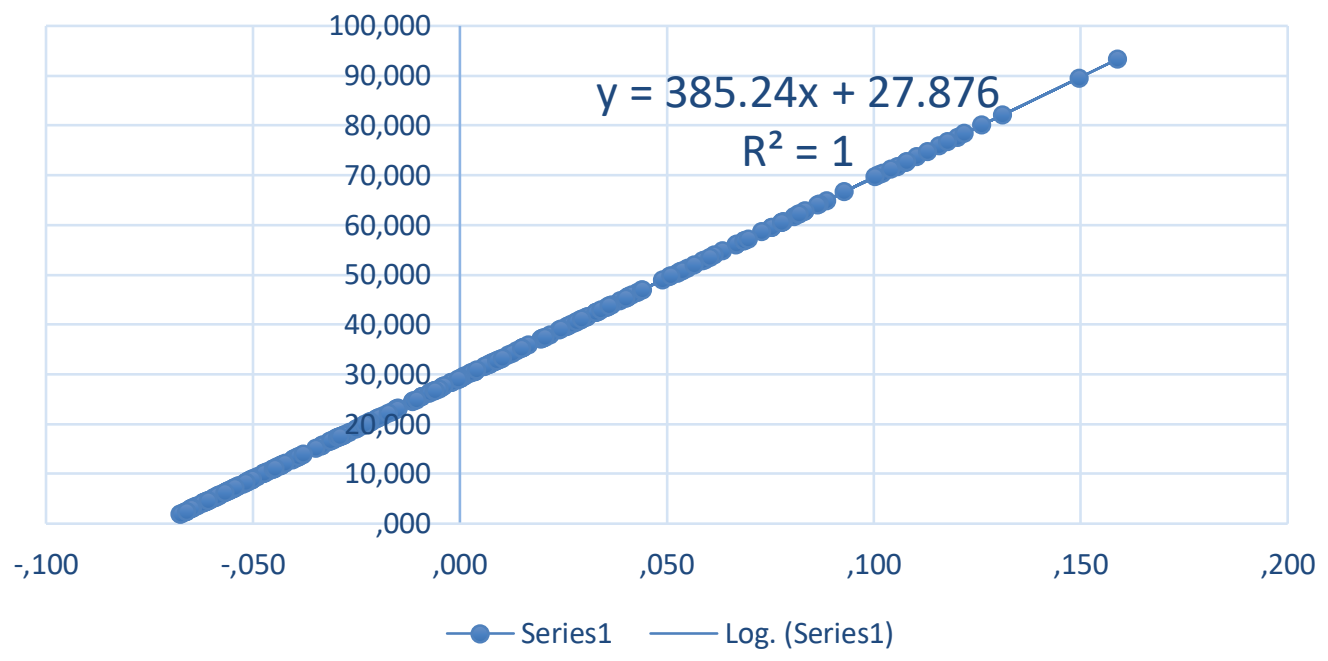

Gambar 3 Grafik Korelasi antara Debit Ketersediaan Air dan Indeks

Dari grafik diatas maka trend bencana kekeringan yang akan datang dapat diperkirakan menggunakan persamaan logaritmik $\mathrm{y}=385,24 \mathrm{x}+27,876$ dengan y debit dan $\mathrm{x}$ adalah indek.

\section{Pemetaan Kekeringan}

Hasil analisa perhitungan indeks kekeringn berdasarkan metode ambang batas selanjutnya diklasifikasikan menurut kriteria kering, setelah itu dipetakan menggunakan software ArcGIS. Warna dalam pemetaan kekeringan berubah dari hijau ke merah tua, dengan keterangan hijau untuk basah, kuning sebagai kering, orange sebagai sangat kering, dan merah sebagai amat sangat kering. Pemetaan kekeringan dapat dilihat pada Gambar 4 - Gambar 13.

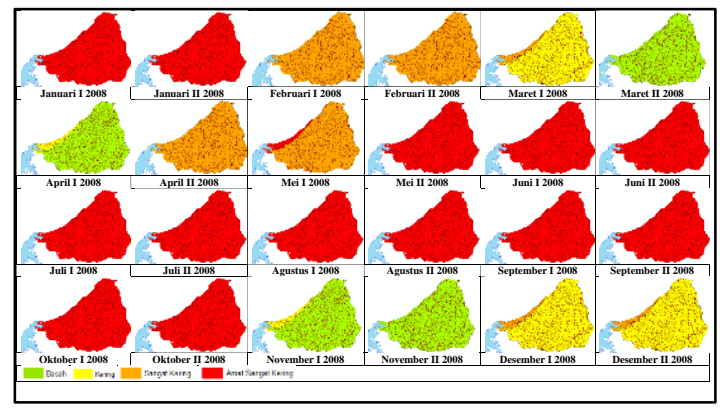

Gambar 4. Pemetaan Tahun 2008

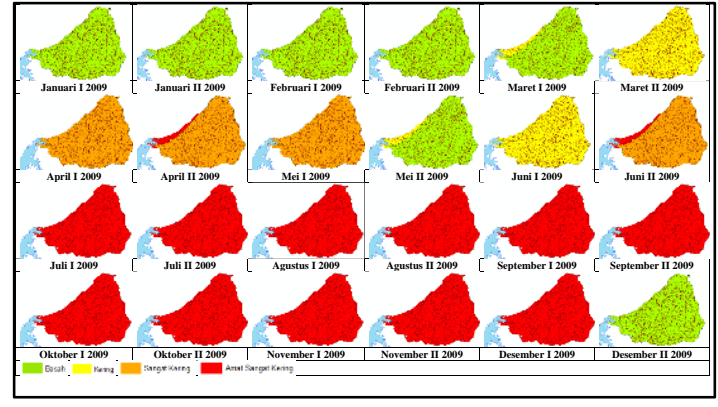

Gambar 5. Pemetaan Tahun 2009 


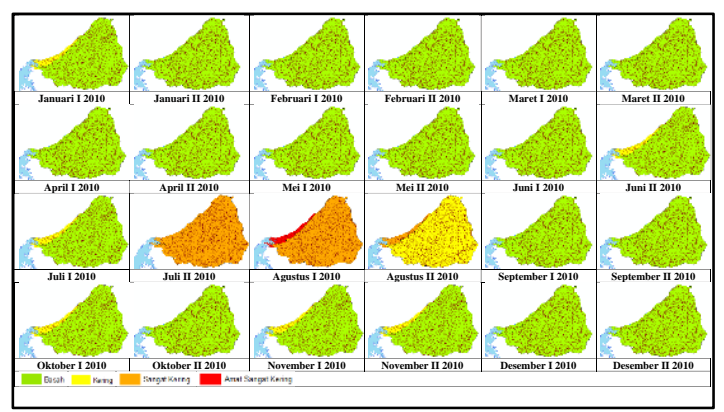

Gambar 6. Pemetaan Tahun 2010

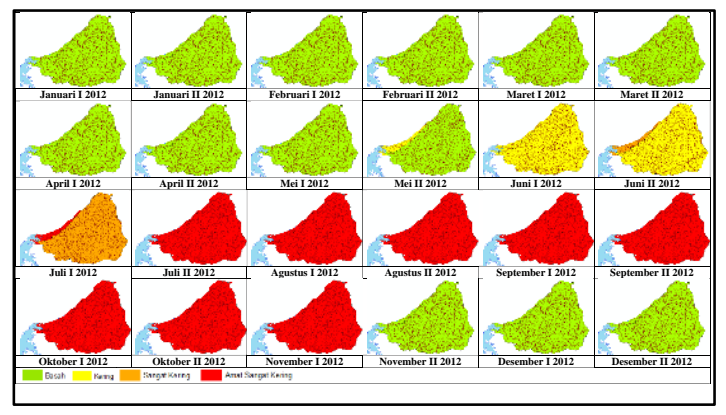

Gambar 8. Pemetaan Tahun 2012

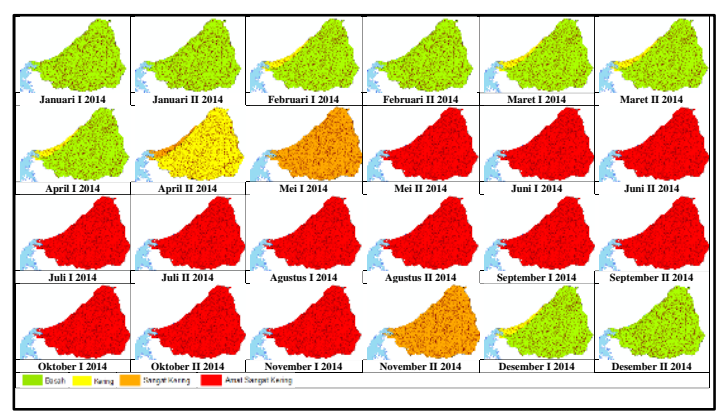

Gambar 10. Pemetaan Tahun 2014

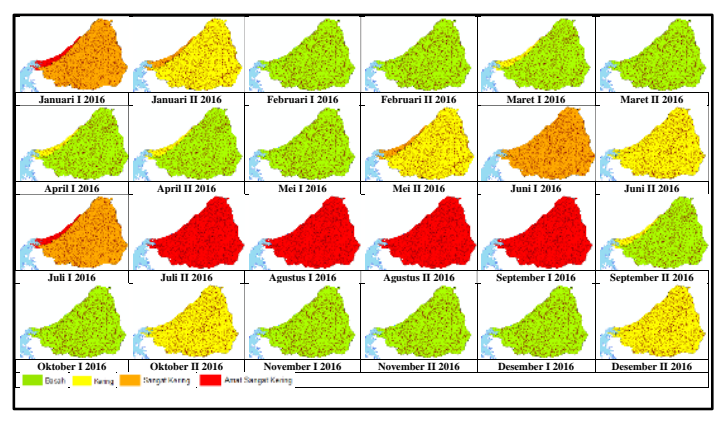

Gambar 12. Pemetaan Tahun 2016

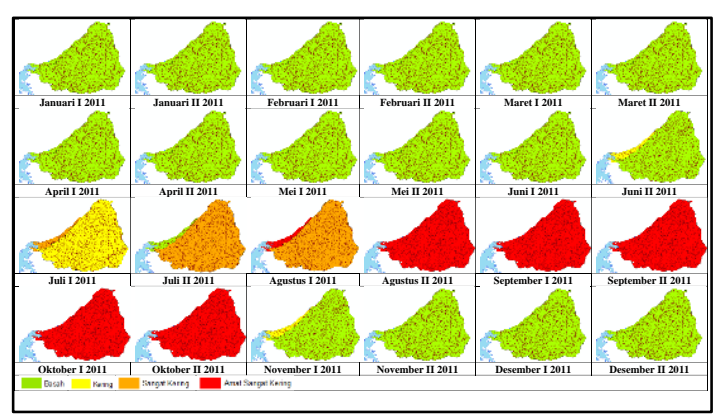

Gambar 7. Pemetaan Tahun 2011

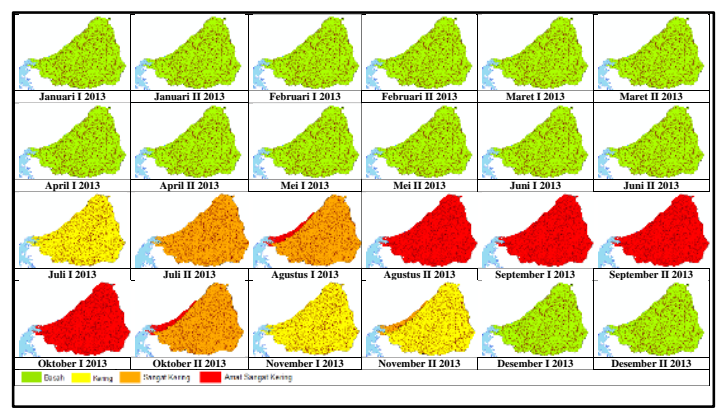

Gambar 9. Pemetaan Tahun 2013

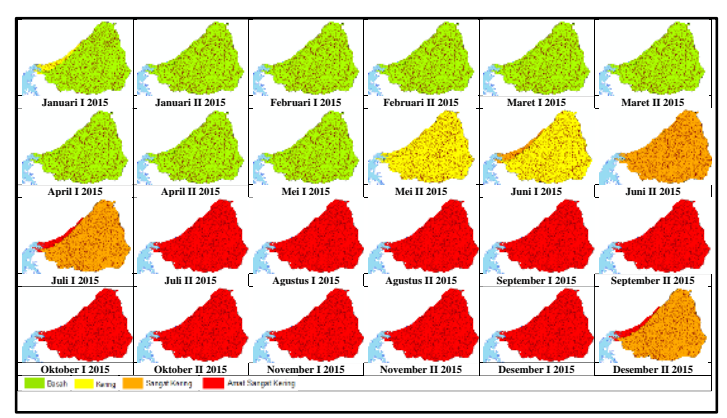

Gambar 11. Pemetaan Tahun 2015

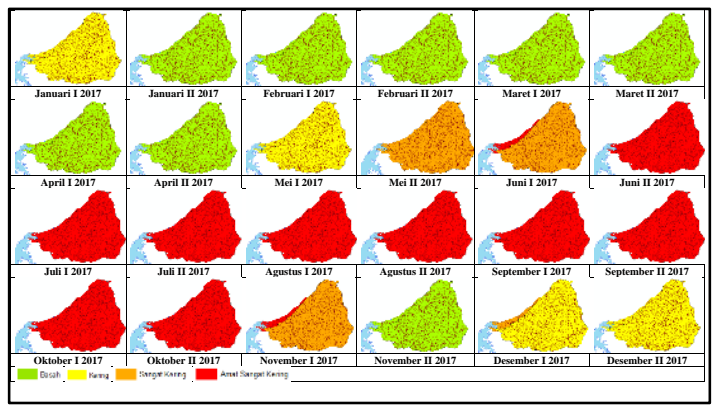

Gambar 13. Pemetaan Tahun 2017

\section{KESIMPULAN}

Kesimpulan yang dapat diambil berdsarkan hasil perhitungan yang telah dilakukan untuk analisa kekeringan yaitu : 
1. Ketersediaan air di Daerah Aliran Sungai (DAS) Keduang dengan perhitungan metode NRECA menghasilkan debit yang bervariasi dengan rentang antara 1,9128 m3/detik sampai dengan 93,5524 m3/detik. Debit - debit yang berada di bawah ambang batas Q50 terjadi secara umum selama 5 bulan yang terjadi pada Bulan Juni hingga Bulan Oktober setiap tahunnya kecuali pada tahun 2010. Namun berdasarkan ambang batas Q80 tidak adanya ketersediaan air terjadi rata - rata selama 2 bulan yang terjadi pada Bulan Agustus hingga Bulan September setiap tahunnya kecuali tahun 2010 yang memiliki ketersediaan air yang berbeda dari tahun - tahun yang lain.

2. Dari hasil analisis maka didapat nilai debit untuk ambang batas debit normal Q50 yaitu sebesar 28,94 m3/detik dan untuk ambang batas debit andalan Q80 sebesar 22,01 $\mathrm{m} 3 /$ detik.

3. Indeks Kekeringan Hidrologi yang dihasilkan bervariasi. Dimana indeks kekeringan terparah terjadi pada periode Oktober II 2014 dengan indeks sebesar - 0,0670 dimana $\mathrm{Q}<(70 \%) \mathrm{Q} 80$ yang mana setara dengan kriteria amat sangat kering. Sedangkan indeks yang paling basah bernilai 0,1601 yang terjadi pada periode Februari II 2013.

4. Grafik yang dibentuk merupakan hubungan debit (sumbu y) dengan indeks kekeringan hidrologi (sumbu x) yang mana menghasilkan sebuah garis lurus yang memiliki persamaan y $=385,24 \mathrm{x}+27,876$. Grafik yang dibentuk memiliki nilai korelasi 1, dimana menunjukan bahwa bentuk data secara umum sama. Persamaan yang dibentuk oleh grafik hanya dapat diterapkan di DAS Keduang.

5. Pemetaan kekeringan di Daerah Aliran Sungai (DAS) Keduang dihasilkan dari data debit yang dibuat guna mengetahui persebaran kekeringan setiap 15 harian yang nantinya dapat digunakan sebagai mitigasi bencana kekeringan di Daerah Aliran Sungai (DAS) Keduang khususnya dan Wonogiri pada umumnya.

\section{DAFTAR PUSTAKA}

Adisamita Raharjo. 2011. Manajemen Transportasi Darat. Graha Ilmu : Yogyakarta.

Adi Prasetya Nugroho. 2011. Analisis Kekeringan Daerah ALiran Sungai Keduang dengan Metode Palmer. Universitas Sebelas Maret : Surakarta.

Afif Amiluddin, Wahyuningsih. 2015. Studi Tentang Kekeringan Hidrologi Menggunakan Metode Ambang Batas (Threshold Level Method) Studi Kasus UPT PSDA di Kediri, Surabaya, dan Pamekasan. Universitas Jember : Jember.

bttp:// www.pu.go.id/main/view pdf/5407 diakses 14 Desember 2017

Ika Suryati.2008. Analisis Hubungan Antara Sebaran Kekeringan Menggunakan Indeks Palmer Dengan Karakteristik Kekeringan. Institut Pertanian Bogor. Bogor.

Lena M. Tallaksen. 2004. On The definition and modelling of streamflow drought duration and deficit volume. Hydrologiccal Science Journal.

Raden Roro Rintis Hadiani. Setiono. 2009. Analysis Pf Rainfall-Runoff Neuron Input Model With Artificial Neural Network. For Simulation For Availability Of Discharge At Bah Bolon Watershed. Sebelas Maret University. Surakarta.

Raden Roro Rintis Hadiani. 2009. Analisis Kekeringan Berdasarkan Data Hidrologi. Disertasi, UNIBRAW, Malang.

SNI 7745 : 2012. Badan Standardisasi Nasional. Tata Cara Perbitungan Evapotranspirasi Tanaman Acuan dengan Metode Penman - Monteith.

Wahyu Hatmoko. 2011. Distribusi Gamma sebagai Penentu Lama Baterai dapat digunakan. Universitas Atma Jaya. Yogyakarta. 